logical theory of a science should be not the terminus a quo of instruction, but the terminus ad quem.

In the proper adjustment of the pupil's work, to use these three appeals for the purpose of education is the urgent problem of the teaching of science to which this committee has addressed itself. To this end curricula for schools on different types, the supply of science teachers in State-aided schools, the academic qualifications of headmasters, and the methods of inspection and examination are all discussed in a very readable and useful report.

\section{THE FUTURE OF SCIENCE IN WALES.}

THE recently issued Report of the Royal Commission on University Education in Wales will, there seems no doubt, mark the beginning of a new era in higher education in the Principality. Into the past history of the University and colleges and the causes which led to the setting up of a Royal Commission we cannot enter here. We are concerned with the future, and, more especially, with the provision to be made for the development of scientific and technological training.

From the very first it was recognised that "science, especially in its applications to arts and manufactures, should occupy a prominent place in the curriculum of the colleges," and provision was made by all three colleges in Wales for the teaching of pure science. The further development of teaching and research in pure science is left to the reorganised University and colleges, which, it is hoped, will be provided with ampler funds for this purpose. We learn, however, that, "as the requirements in pure science became satisfied, the special needs of the neighbouring localities began to claim the attention of the colleges "'; and the demand has arisen for the further development of teaching and training in applied science. It is earnestly to be hoped that, as a result of the recommendations made by the Commission, the University and colleges of Wales will be able to develop their work in these branches to a level unsurpassed by any other British university.

As regards the prominence of the demand for increased provision for technological and vocational studies, wise words of warning are spoken by the Commissioners which all interested in true University education and in the highest development of our industries would do well to ponder and lay to heart :-

Although it is right that the universities should be looked to as schools of preparation for professional life, it would be fatal if they allowed preoccupation with this task to weaken their hold upon the principle that they are intellectual trustees for posterity, keeping safe and, where possible, adding to the stock of universal knowledge which the past has entrusted to their care. . . Some people have been inclined to complain that the universities turn out graduates who with all their attainments are not always immediately serviceable in commerce and industry: a right view of what a university training seeks to do for its NO. 2529, VOL. IOI] students would suggest to such people that even their own utilitarian aims would not be really served by importing a more definitely technical element into the university student's course. As year by year commerce and industry become more complex and farreaching in their ramifications, the value of a sound grasp of principles grows more indispensable to those concerned in their higher operations, and any loss on this side would be but ill.made up by a slightly earlier familiarity with the specialised technique of a particular trade or calling, which after all is easily and rapidly acquired by a mind properly grounded in principles.

We commend these words to the careful attention of the people of Wales.

In Mid and North Wales, which are largery agricultural in character, we find that in the colleges of Aberystwyth and Bangor agriculture has for long been included among the subjects of the college curricula. But with regard to the fuller development of their agricultural departments which both colleges desire to promote, important pronouncements are made by the Commissioners. The present three years' degree course, it is maintained, which is primarily based on science, is inadequate for teachers and experts, because the student does not obtain that thorough grounding in pure science which would qualify him to undertake fruitful research work after he has obtained his degree. Such a student would do better to obtain his degree in one of the pure science departments and then pass over to the agricultural department for some general training in agriculture, coupled with investigation in his special subject. He requires, in fact, at least a five years' course, and his agricultural training should in the main be post-graduate. Since for this purpose elaborate provision of staff and equipment is needed, such advanced training should be concentrated at a single college. For the working farmer a new type of degree course is required, based more upon economics and history than upon pure science, and this course should be provided at all constituent colleges undertaking agricultural teaching and advisory work. A department of animal pathology should be established as part of the College of Medicine at Cardiff.

With regard to forestry, future developments will depend on the policy of the Government in respect to afforestation. It is, however, laid down that forestry should in the main be treated as a post-graduate subject, and, for reasons of economy, should be associated with the postgraduate department of agriculture at whichever college this department may be located.

In South Wales, as is natural, the demand is mainly for further development in technological training in engineering, mining, snd metallurgy; and a scheme has been drawn up for the constitution of a faculty and board of technology. According to this scheme, which is accepted in its broad outlines by the Commission, the Municipal Technical College of Swansea would become recognised as a fourth constituent college of the University; and, subject to the fulfilment of certain conditions designed to secure a satisfactory 
standard, post-secondary institutions and departments doing advanced work might be recognised as providing part of the courses for a distinct technological degree which the University would establish.

By the institution of this new faculty and board, on which the local industries would be represented, it has been sought to meet "the strong feeling of distrust entertained towards the University and centralised control by certain industrial and commercial interests in South Wales." In relation to the University this new faculty and board "should have all reasonable liberty to bring their special knowledge and experience to bear on what will often be local problems, but they cannot claim to be given a greater degree of independence than that enjoyed by a constituent college. It is conceivable, for example, that individuals or associations may desire to place large sums of money at the disposal of the board, and that by these means, or in other ways, the faculty and board of technology might be able to give a bias to the general development of the colleges or to the character of courses for degrees which would be contrary to the general principles upon which our recommendations are framed and inconsistent with any real control on the part of the University or the colleges." The Commissioners utter this warning :-

But there is a serious danger lest short views should be taken of the true function of the university, and of the nature of the contributions to the common good which it is most fitted to make. Great advances in the application of science to industry have often been made possible by the discoveries of students who had no such object in view, but were impelled simply by the desire to extend the bounds of knowledge and solve some problem in the realm of pure science.

$\mathrm{W}$ th regard to the development of medical studies it is recommended that the proposed National School of Medicine should be organised as an independent constituent college of the University governed by a council and senate of its own. Towards the erection of the necessary buildings the sum of $90,000 l$. has been promised by a private donor, and the gift of a further sum of $30,000 l$. has recently been announced for the endowment of a chair of preventive medicine.

On the financial side it is recognised that, in order to carry out all the legitimate developments of the work of the University and its colleges, an additional annual income of about roo,oool. will be necessary, to be raised by increased local subscriptions and private gifts and by a proportionate increase of the Government grant; and it is held that increased remuneration and provision for superannuation for the teaching staffs of the colleges constitute a foremost claim on such increased revenue.

The principles and recommendations put forward by the Commissioners afford an excellent opportunity for renewed effort, and if the people of Wales will rise to the height of their opportunity, higher education in science and technolngy is assured of a bright future in the Principality.

NO. 2529, VOL. IOI]

\section{ANATOMICAL NOMENCLATURE.}

$\mathrm{A}^{\mathrm{T}}$ a recent meeting of the Anatomical Society 1 of Great Britain and Ireland steps were taken to clear up the chaos which has overtaken the nomenclature employed by human and vertebrate anatomists in this country. In 1889 the Anatomical Society of Germany appointed a commission to prepare a revised nomenclature--one which was finally adopted by the society when it met at Basle in 1895, and hence known as the "Basle Nomina Anatomica," usually spoken of as the B.N.A. nomenclature. The majority of British anatomists have never favoured or accepted the B.N.A. nomenclature, not because of its origin, but because of its intrinsic defects. The French and Italian anatomists also refused to adopt it. Unfortunately, the Basle terminology has been adopted in our leading English text-books on human anatomy, while the majority of teachers have continued to use the terminology. which is native to Britain. The result has been to introduce a state of chaos bewildering to the pupil as well as to the teacher.

The resolution passed unanimously by the Anatomical Scciety at its meeting in King's College on March $\mathrm{I}$ is a definite pronouncement against the adoption of the Basle nomenclature by British anatomists. The terms of the resolution were as follows :-

This society sees no reason for departing from the use of the old nomenclature as the recognised medium of description for employment in anatomical text-books and departments or by medical men in general. On the other hand, it thinks there are very good reasons to be urged against the adoption of any other nomenclature for this purpose.

\section{NOTES.}

THE Bakerian lecture of the Royal Society will be delivered on 'Thursday, April 25, by Sir Charles Parsons, on "Experiments on the Production of Diamond." Sir Charles Parsons will also describe his experiments on the formation of the diamond at the eighth annual May lecture which he is to give before the Institute of Metals on May 2. In view of the special character of the occasion, the council of the Institute of Metals has decided to make this an open meeting. Persons desiring to be present should apply -enclosing a stamped and addressed envelope-for cards of invitation to Mr. G. Shaw Scott, 36 Victoria Street, S.W.I.

THE council of the Royal Society has appointed a committee to irivestigate and report on the possibility of obtaining and replacing food materials and other necessaries by the utilisation of natural products not hitherto generally employed for such purposes. Suggestions as to such products and the means of organising their collection should be addressed to the secretary of the Natural Products Committee, Royal Society, Burlington House, Piccadilly, London, W.I.

THE secretary of the Decimal Association informs us that at the annual meeting of the Associated Chambers of Commerce held on April 9 and ro a motion was adopted urging the Government to pass into law the Decimal Coinage Bill prepared by the Executive Council of the Associated Chambers of Commerce in 